\title{
19. \\ VLADAN DESNICA, \\ PREVODITELJ I KOMENTATOR \\ FOSCOLOVIH GROBOVA
}

\section{Sanja Roić i Iva Grgić Maroević}

UDK: 821.131.1Foscolo, U.=163.42

Izvorni znanstveni članak

Sažetak: Važno mjesto u opusu Vladana Desnice zauzima prijevod s talijanskog jezika Foscolova kratkog epa Grobovi, objavljen u zagrebačkom časopisu Hrvatsko kolo 1951. godine. Talijanski pjesnik, romanopisac, kritičar i prevoditelj Ugo Foscolo (1778. - 1827.), rođen u Grčkoj, odgojen u Dalmaciji (Splitu), kako se običavao predstavljati, svojim je spjevom objavljenim 1807. dao snažan poticaj talijanskoj preporodnoj misli i sveukupnom književnom izričaju svoga vremena. Grobovi su se integralno prevodili više puta između 1869. i 1990. godine u časopisima koji su izlazili u Zagrebu, Dubrovniku, Novom Sadu, Mostaru i Splitu. Nazorov je prijevod ostao u rukopisu, a Desničin je jedanaesti po redu. Posljednji je, za sada, objavio Frano Čale 1990. godine u časopisu Forum i godinu dana kasnije u knjizi Ode. Soneti. Grobovi. Rad analizira i ocjenjuje Desničin prijevod s traduktološkog stanovišta i smješta ga u njegov talijanistički prijevodni opus.

Ključne riječi: Ugo Foscolo, ep Grobovi, talijansko-hrvatski prijevod, nerimovani jedanaesterac, simbolika i metaforika groba

oji su motivi naveli Vladana Desnicu da se početkom 50-ih godina prihvati prevođenja Foscolovih Grobova? Kakva je kvaliteta toga prijevoda i kakvo mjesto on zauzima u autorovu prevoditeljskom, a zatim i spisateljskom opusu? Kao što je poznato, Vladan Desnica u dijalogu je s talijanskom kulturom od rane mladosti i već je tada bio zaokupljen razmišljanjem o svojim precima i o povijesnim okolnostima koje su njegovu obitelj vezivale za Islam Grčki. O tome napisao je donedavno nepoznatu dugu pjesmu i uz očevu je redakciju preveo na talijanski jezik. ${ }^{1} \mathrm{O}$ kući, znamenu i simbolu ovozemaljskog trajanja, pjevao je mladić, a zreli muškarac prihvaća se prijevoda s talijanskog jezika neoklasičnog epa Grobo$v i$ koji korespondira, $s$ jedne strane, s preporodnom mišlju ponajviše devetnaestostoljetnih dalmatinskih intelektualaca, a s druge je u znatnoj opreci s poslijeratnim književnim i kul-

1 Usp. Sanja Roić, „Dom predaka u Islamu Grčkom kao pjesnički motiv. Jedna nepoznata pjesma na talijanskom jeziku iz arhiva obitelji Desnica“, Hrvatsko-srpski /srpsko-hrvatski interkulturalizam danas (ur. Drago Roksandić), Zagreb 2017., 307-319. 
turnim kanonom. No, prošlo je tek nekoliko godina od završetka rata na čijem je početku umro njegov otac, a na samom kraju stric, s kojim su ga vezivali ne samo rodbinski nego i prijateljski i intelektualni odnosi.

Vladan Desnica posreduje i prenosi talijansku kulturu u jezik i kulturnu sredinu svoga zavičaja (sjeverne i srednje Dalmacije) još od 1930-ih godina, kada je u vlastitoj nakladi tiskao Croceove eseje. Dalmacija je u središtu njegovih književnih i muzikoloških interesa, s cezurom koja nastaje zbog ratnih prilika i gubitka rukopisa prilikom selidbe 1942. iz Splita preko Šibenika u Islam. Desničini prevoditeljski izbori Crocea, Carduccija, Leopardija i Foscola nadovezuju se na stričeve prijevode, ${ }^{2}$ pa ako je Benedetto Croce bio njihov suvremenik (umro je 1952.), potonja su trojica nedvojbeno klasici talijanske književnosti. Tim izborom Vladan Desnica ponovno promišlja književne i estetske vrijednosti talijanskih predložaka i mogućnost njihova očuvanja, prijenosa i posredovanja na svom jeziku u kulturi primateljici. U skladu s postavkama suvremene traduktologije, čija saznanja dobro sažima suvremeni talijanski teoretičar prevođenja Bruno Osimo, smatramo da svaki prevoditelj posjeduje vlastitu poetiku prevođenja koja se, u slučaju pojedinog prijevoda, prenosi izabranom dominantom (ključem čitanja/prevođenja, tj. estetskim nukleusom) na ne nužno isti model čitatelja, zbog čega je u znanstvenom diskursu o prevođenju korisno govoriti o prijevodima koji obavljaju različite funkcije. ${ }^{3}$

Godine je 1950. Desnica objavio Zimsko ljetovanje, kratak roman koji tadašnja kritika nije prihvatila i čije će vrijednosti tek kasnije postati dijelom naše književne i kulturne baštine. Istodobno, već radi i na drugom romanu, Proljećima Ivana Galeba, čije sekvencije često promišlja na talijanskom jeziku. Profesionalni književnik od 1949., Desnica uskoro počinje prevoditi roman Kruh i vino Ignazija Silonea ${ }^{4}$ i studiju Lionella Venturija Od Giotta do Chagalla, a oba će djela biti tiskana 1952. Godine 1950. objavio je prijevod i popratan tekst o Cavalcantijevoj baladici u zagrebačkom časopisu Hrvatsko kolo, ${ }^{5}$ a u idućem godištu istog časopisa izlaze njegov prijevod Foscolovih Grobova i bilješke uz prijevod. ${ }^{6}$ Desničini se komentari oslanjaju na pouzdane talijanske izvore, a prema rukopisnom fragmentu sačuvanom u osobnoj ostavštini, primjećujemo da ih je za tisak znatno skraćivao. ${ }^{7}$ Nije jasno, međutim, zbog čega se u časopisu komentari prekidaju nakon 160. stiha, ako je poznato da

$\overline{2} \quad$ Riječ je o prijevodu Croceova eseja O jednom karakteru novije talijanske književnosti, Carduccijevih pjesama Na izvoru Klitumna, Pobjeda, Aleksandrija i Na brdu Mariju, Leopardijeve pjesme Z̈ukva ili cvet pustinje. Usp. Boško DesniCA, Sabrana djela, Zagreb 2008., 487-500; 461-472, 473-481. Prevedeni fragment iz Foscolovih Grobova objavljen u Srpskom književnom glasniku nije uvršten u Sabrana djela Boška Desnice. Usp. bilj. 12 u ovom radu. Dodajemo da se u Sabranim djelima pogrešno navodi Carducci kao autor prevedene pjesme Zukva ili cvet pustinje. Usp. B. Desnica, Sabrana djela, 473.

3 Usp. Bruno Osimo, Traduzione e qualità, Milano 2004., 149; Isti, Storia della traduzione, Milano 2002.; Iva Grgić Maroević, Poetike prevodenja. O hrvatskim prijevodima talijanske poezije, Zagreb 2009., 114.

4 Pretpostavljamo da je Desnica preveo Siloneov roman imajući na umu odnos kritike prema književnom djelu u objema poslijeratnim intelektualnim sredinama, talijanskoj i jugoslavenskoj. Usp. Sanja Rorć, „Dva pisca na meti kritike: Desnica i Silone“, Istočno i zapadno od Trsta. Interkulturalni dijalozi, Zagreb 2013., 122-141.

5 Guido Cavalcanti, „Balateta“, Hrvatsko kolo, 3/1950., br. 4, 652-653; Vladan Desnica, „Guido Cavalcanti: uz prijevod 'balatete'“, Hrvatsko kolo, 3/1950., br. 4, 768-777. O tom prijevodu i komentaru usp. Sanja Rorć, „Desnica i 'pramaljeće' talijanskog pjesništva“, Stranci. Portreti s margine, granice i periferije, Zagreb 2006., 144-157.

6 Usp. „Ugo Foscolo: Grobovi'. Prev. Vladan Desnica“, Hrvatsko kolo, 4/1951., br. 3-4, 281-287; V[ladan] D[esNica], „Bilješke o 'Grobovima' Uga Foscola“, Hrvatsko kolo, 4/1951., br. 3-4, 386-387.

7 Vladan Desnica, „Bilješke o ‘Grobovima’ Uga Foscola“, strojopis, Osobna ostavština Vladana Desnice u Zagrebu. 
Foscolov spjev broji 295 stihova, pa pretpostavljamo da je do propusta došlo pri uređivanju časopisa (urednici su bili Joža Horvat i Gustav Krklec; Krklec je bio i odgovorni urednik). ${ }^{8}$

U Osobnoj ostavštini Vladana Desnice pronašle smo strojopisnu kopiju neobjavljene 3. i 4. stranice komentara, gdje Desnica komentira još šesnaest mjesta u epu, završno s 290. stihom. ${ }^{9}$ Isto tako, premda smo pretpostavljale da je Desnica uz prijevod morao prirediti i bilješku o piscu, bezuspješno smo je tražile u istom broju i u narednim godištima Hrvatskog kola jer ona nije ni bila objavljena. ${ }^{10} \mathrm{U}$ toj bilješci Desnica ističe nekoliko važnih podataka o autoru i djelu: Ugo Foscolo rodio se na grčkom otoku Zakintu (Zakintos), nekoliko godina djetinjstva proživio je u Splitu, a njegovo je remek-djelo spjev Grobovi. I dalje:

U Foscolu, pored istaknutih klasičnih reminiscencija, mitoloških diskurza i asocijacija, osjećamo jako duh čovjeka njegova vremena, dah romantičke epohe na pomolu; pored plastične skulpturnosti i klasične čistote linije, nalazimo uzburkani duh i upaljivi temperament romantika. Klasične reminiscencije kod njega, rođenog Grka, nisu puki i mrtvi dekor kao kod drugih talijanskih pisaca njegova i ranijih vremena; ima tu mnogo viđenog i prisno doživljenog, ima tu grčkog pejsaža. I osvjetljenja, i atmosfere, svega onoga što je iz djetinjstva ponio u očima i u duši. (...) On je, naprotiv u riječima vrlo ekonomičan, precizan u izrazu, krajnje koncizan i koncentriran. Otuda i jedrina i plastičnost njegovih slika. Ta se konciznost najbolje može iskusiti kod prevođenja. Prevodilac nailazi na neslućene teškoće, i pored toga što je originalan u nerimovanim jedanaestercima. ${ }^{11}$

Vladan Desnica ne spominje objavljen fragment Grobova u prijevodu svoga strica Boška, no u osobnoj ostavštini, u mapi naslovljenoj „Foscolo 1778-1827“, nalazi se prijepis zelenom tintom toga fragmenta pisan rukom Vladana Desnice. ${ }^{12}$ Godine 1951., kad izlazi Vladanov prijevod u Hrvatskom kolu, Boško Desnica nije među živima već šest godina. U svakom slučaju, možemo anticipirati da su poetike prevođenja dvojice Desnica bile različite, a da su obojica polazni jezik, jezik originala, označavala „talijanskim“.

Kratak ep Grobovi (Dei Sepolcri) napisan je 1806. godine, povodom Napoleonova edikta o grobljima, objavljen 1807. i posvećen Ippolitu Pindemonteu, autorovu suvremeniku, klasicističkom pjesniku i prevoditelju Odiseje na talijanski jezik. Epigraf mu je navod s rimskih Dvanaest ploča (450. n. e.), u kojima se spominju prava duša umrlih kao temelj rimskog prava. O uredbi napoleonske vlasti u Italiji o grobljima, koja zbog sanitarnih razloga moraju biti izmještena iz središta naseljenih mjesta i na kojima će

8 U Biblioteci Matice hrvatske doznale smo da se arhiva časopisa Hrvatsko kolo nalazi u Hrvatskom državnom arhivu u Zagrebu. Prema podacima u Matici, u njemu nema podataka o objavljivanju prijevoda Uga Foscola. Preostaje još eventualno uvid u osobnu prepisku urednika.

$9 \quad$ Zahvaljujemo dr. sc. Urošu Desnici na mogućnosti konzultiranja Osobne ostavštine Vladana Desnice u Zagrebu.

10 Prevoditeljeva bilješka „Ugo Foscolo (1778-1827.) (bilješka o piscu)“ objavljena je u knjizi Hotimično iskustvo: diskurzivna proza Vladana Desnice. Knjiga prva (prir. Dušan Marinković), Zagreb 2005., 251-252, odakle ćemo je citirati. Marinković preuzima tekst bilješke iz knjige Eseji, kritike, pogledi (ur. Stanko Korać), Zagreb 1975., 145-147. Međutim, ni prvi ni drugi urednik nije provjerio nalazi li se doista Desničina bilješka u broju 3-4 Hrvatskog kola za 1951. godinu jer obojica citiraju navodni izvor kao „Hrvatsko kolo, Zagreb, 1951.“. U mapi „Foscolo 1778-1827“ u Osobnoj ostavštini Vladana Desnice u Zagrebu nalazi se i rukopisni fragment „Večeri“, prijevod glasovitog Foscolova soneta Alla sera.

11 V. Desnica, „Ugo Foscolo (1778-1827.) (bilješka o piscu)“, 251.

12 U potpisu prevedenog ulomka od 263. do 295. stiha stoji: „S talijanskog preveo Boško Desnica“. Usp. Ugo Foskolo, „Kasandrin plač. Ulomak iz 'Grobova'“, Srpski književni glasnik, 10/1910., knj. 24, 268. 
stin

16

Ippolito P1ndemonte / $1753-1828 /$, kome je spjev posvé́en, je menj1 talijanski pjeanik, is Verome. P1 seo je "Poeale canpeatri* 7roljace pjestee/, "Epistole in versi" /P1 sme a stihovilad, sat1= ricke "Serwone" /Propovijeds/, a odgovorio je Poscolu svojin apje= voll iste ms ters. Posmat je njegov prevod Odiseje.

$21-22$

Briteao $t 1 \mathrm{~h}$ st1hova jo muten 1 preporen. Bto to anadi de vrljeme a svoie toku pretvara 1 preobraxava no gamo govjeka, nego 1 njegov grob, pa posijednj1 vid Lega? oovjelca? - ta o ajemu je ŏas prim

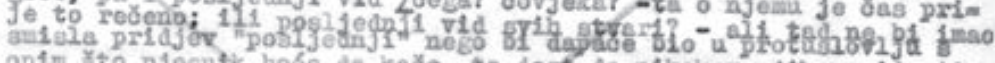
onfin sto pjeanti hoce da kaze, to jegt de nikekev njlihov vid nije posijeinj1, ve6 jemo jedan od neorgjensh prelarnith vidova 1 oblike. Iarodito su nojean 1 preporge and "ostsod zemije 1 neba". Io= nentetor de apinja de ramovrapim, vrlo deleicim 1 alabo uvjerij1=

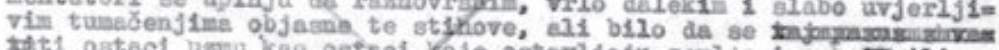
aAt1 osteol parma keo ostsol Koje ostavljaju zeml.ja i nebox 121 kao ostaol koj1 ostaju od ptmlje 1 neba, stihovi jednako ostaja

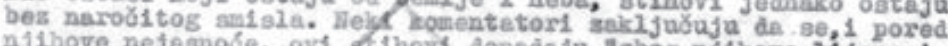

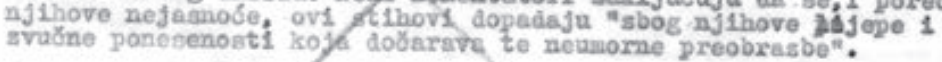

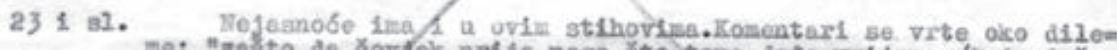
me: "zasto de roydek prije nego g to tome dode vri.jeme, $/ t \cdot j$. joj

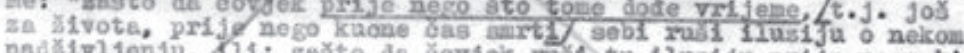

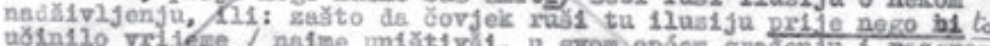

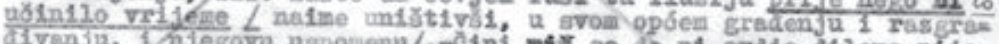
divenju, isjegova uspomeng/. -cini wes e da ni ovdje dileme nije od narodjtog maćaje.

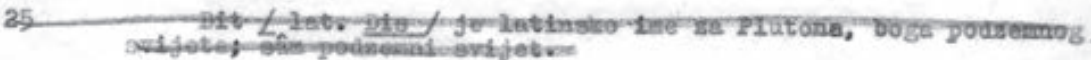

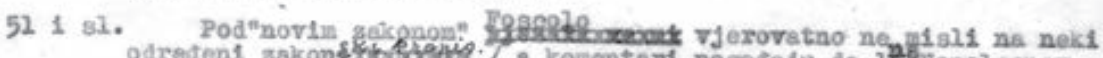

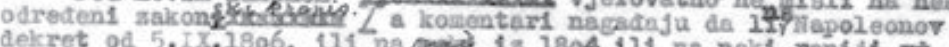

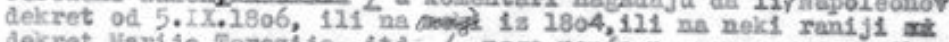
dekret Marije Fereaije, 1td.j, nego nogo na savreneme uredbo 1 obiŏaje koje je sevela rrancuka revoluo1je s koje su sabranjivale da se mrtvi pokepaju u cricvana 1 sl.p veo jedino u narooritin javnin grobistima vaia gradsich naselja; - "Ime umrlim kratin - ne trebs ghvatit1 dosiovno, kso da fe bilo zabranjeno na grobu nasmediti

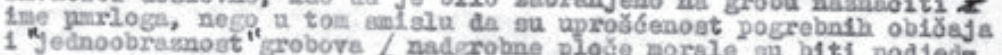
1 Jednoobramost" "Grobove L naderobne plose morale gu biti podjede

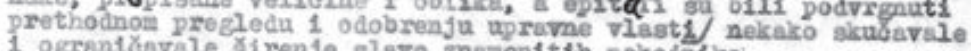
1 ogrentöavale orirenje slave meatenttih pokojnika.

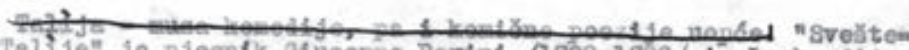
nik Talije" je pjeanik a1usopje Parind /1729-1799/, 1s Lombardije;

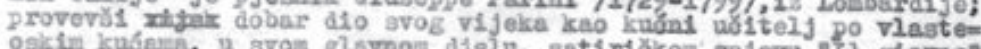

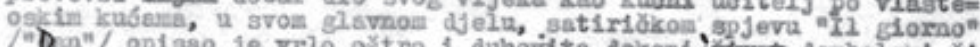

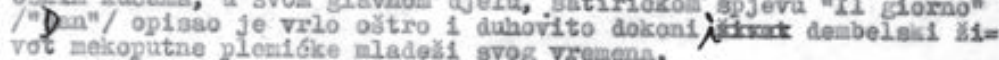

"Lombarasict Berdanepei"

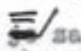

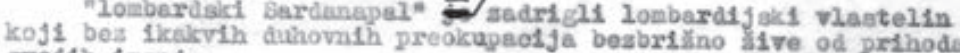
grojih inanja.

Sl. 1. Redigirani strojopis Desničinih bilješki uz prijevod Grobova Uga Foscola

spomenici trebati biti uniformirani, žustro se raspravljalo u salonima koje su posjećivala obojica književnika.

Treba se podsjetiti da je koncem 18. stoljeća nakon pada Venecije dio Italije u kojem je Foscolo živio nakon što je obitelj napustila Split potpao pod tuđinsku vlast najprije Austrije, a zatim Napoleona. No, Talijanima je ostao vječni znamen grobova slavnih predaka, pri 
čemu je grob bio shvaćen kao znak, kao metafora besmrtnosti ideje ljepote i poezije koju su stvorili klasični i moderni velikani, ideja na koju će se nadovezati preporodni pokret za ujedinjenu Italiju. U početnom dijelu epa prepoznaje se utjecaj klasičnih pisaca, osobito Lukrecijeva spjeva $O$ prirodi.

Unutar odnosa hrvatske i srpske kulture prema talijanskoj, stoljećima za njih referentnoj, ističe se interes za Uga Foscola (u prvom redu njegov spjev Grobovi), potvrđen prijevodima, kojih je šest u 19. stoljeću (Ivan Trnski 1869.; Vladislav Vežić 1870.; Stjepan Buzolić 1879.; Lazar Tomanović 1883.; Luka Svilović 1885.; Marko Car 1887.) te isto toliko u 20. stoljeću (Antun Sasso 1902.; Stjepko Ilijić 1905.; Vinko Lozovina 1911.; Vladimir Nazor 1939.; ${ }^{13}$ Vladan Desnica 1951.; Frano Čale 1990.). Ponajprije valja istaknuti da je u Desničinu prijevodu broj stihova jednak broju stihova originala, što raniji prevoditelji Ilijić, Sasso i Buzolić nisu uspjeli postići. Također, Desnica nerimovani jedanaesterac, klasičan stih talijanskog pjesništva od njegovih početaka, prevodi također nerimovanim jedanaestercem, za razliku od ranijih prevoditelja, koji su prevodili desetercem. Brojna opkoračenja u originalu prevoditelj čuva i u prijevodu, čime "proširuje“ stih. Ove dvije karakteristike postale su standardom talijansko-hrvatskog pjesničkog prevođenja nakon izdanja Danteova Pakla i Čistilišta u prijevodu Mihovila Kombola (1948. i 1955.). ${ }^{14}$

Još jedna od poteškoća pri prevođenju Foscolovih stihova na hrvatski jest konciznost originala. Premda je u odnosu na talijanski jezik hrvatski sintetičniji, Desnica na pojedinim mjestima nastoji još više sažeti dolazni stih. Na primjer, Foscolov fragment „dentro l'urne / confortate di pianto“ (stihovi 1-2) Desnica prevodi autorskim sažimanjem: „u grobu / oplakivanu“ (1-2); Foscolovu sintagmu „sonno / della morte“ (2-3) Desnica prevodi kao „san smrti“ (3) i provodi sažimanje koje nalaže narav hrvatskog jezika; sažimanje ekvivalentom, sintetičnim komparativom; autorov pridjev „men duro“ u značenju „manje težak“ (3) prevoditelj sažima u komparativ „lakši“ (2).

$\mathrm{Na}$ fonološkoj razini u zamjenu za asonancu $o$ u početnim stihovima koja priziva plač, žalost, tugu, Desnica unosi asonancu vokala $u$ :

All'ombra dei cipressi e dentro l'urne
confortate di pianto è forse il sonno
della morte men duro? Ove più il Sole
$\begin{aligned} & \text { per me alla terra non fecondi questa } \\ & \text { bella d'erbe famiglia e d'animali, }\end{aligned}$

13 Taj Nazorov prijevod nije objavljen u cijelosti. Dijelove je u svom radu objavio Josip Jernej. Usp. Josip JerneJ, „Foscolo presso i Croati e i Serbi“", Studia Romanica et Anglica Zagrabiensia, 2/1957., br. 4, 30-31. U bilješci na str. 30 stoji da je prijepis iz rukopisa obavljen uz dopuštenje prevoditelja, što znači da ju je autor članka dobio još za Nazorova života. Jernej spominje još jedan prijevod u rukopisu, Tome Brajkovića, koji je u svom radu naveo Stjepko Ilijić, kao i fragment Grobova, odnosno posljednjih 38 stihova epa, koje je preveo i objavio Boško Desnica u Srpskom književnom glasniku. U to vrijeme Boško Desnica bio je student prava u Beču, a diplomirao je 1912. godine. Usp. Isto, 5. U Osobnoj ostavštini Vladana Desnice u navedenoj mapi „Foscolo 1778-1827“ nalazi se strojopisna kopija Nazorova prijevoda Grobova, fragment stihova 1-40. Usp. bilj. 10.

14 O tome usp. I. Grgić Maroević, Poetike prevodenja. O hrvatskim prijevodima talijanske poezije, 82 i dalje. Zanimljivo je da je Kombolov prijevod V. pjevanja Cistilista objavljen u istom broju Hrvatskog kola kao i prijevod Foscolovih Grobova. 
$\mathbf{U}$ čempresovu hladu il $\mathbf{u}$ grobu

oplakivanu, zar je išta lakši

san smrti? Kada više za me sunce

plodilo zemlji već ne bude ovu

lijepu obitelj živina i bilja
1

$$
10 \mathrm{x} \text { vokal u }
$$

Desnica ne slijedi Foscolovu uporabu velikog slova kod Sole, Speme, Iddio, Dea, Geni, Numi (sunce, nada, božjega, boginja, geniji, bogovi), ali poštuje Natura (Narav), Lari (Lari) i uvodi veliko početno slovo kod sljedećih leksema: tempo (Vrijeme), prode (Junak), grande (Velikan). ${ }^{15}$ Ipak, u predzadnjem stihu epa (294) slijedi majuskulu orginala: Sole = Sunce. Valja napomenuti da za Foscola pojmovi Sole i Natura imaju posebno značenje u heliocentričnom sustavu prirode koja se ciklički obnavlja i u kojoj, prema njegovu mišljenju, nema mjesta ni za transcendenciju ni za metafiziku. Prevoditeljeva redukcija majuskula mogla bi se objasniti nakanom izbjegavanja patetike, karakterističnom za pristup kako poeziji tako i realnoj zbilji u kulturi primateljici, jugoslavenskoj kulturi 50-ih godina prošlog stoljeća. ${ }^{16}$

Kada je riječ o morfosintaktičkoj razini spjeva, zanimljiv je primjer gramatičkog tretmana metonimije u početnim stihovima, gdje Foscolo koristi elidirani plural („l'urne confortate“), a prevoditelj singular „u grobu oplakivanu“, koji zamjenjuje plural:
All'ombra dei cipressi e dentro l'urne
1 ključna riječ u pluralu
confortate di pianto è forse il sonno
della morte men duro? Ove più il Sole
per me alla terra non fecondi questa
bella d'erbe famiglia e d'animali,
U čempresovu hladu il u grobu
1 metonimija, ključna riječ u singularu
oplakivanu, zar je išta lakši
san smrti? Kada više za me sunce
plodilo zemlji već ne bude ovu
lijepu obitelj živina i bilja;

Jednako su tako u kasnijem fragmentu „affetti“ (osjećaji) zamijenjeni singularom „ljubav“, a „templi acherontei“ (aherontski hramovi) singularom „hadski plač":

15 Usporedile smo kritičko izdanje Grobova iz sabranih djela Uga Foscola. Usp. Ugo Foscolo, Poesie e carmi. Poesie. Dei Sepolcri. Poesie postume. Le Grazie (prir. Francesco Pagliai, Gianfranco Folena i Mario Scotti), Firenze 1985. No, često u različitim izdanjima ovog epa varira uporaba velikog slova. Pretpostavljamo da je Desnica pred sobom kao polazni tekst imao talijansko izdanje iz kućne biblioteke: Isti, Poesie. Liriche scelte, Torino 1897. Usp. „Popis kućne biblioteke Vladana Desnice“, Hotimično iskustvo: diskurzivna proza Vladana Desnice. Knjiga druga (prir. Dušan Marinković), Zagreb 2006., 252. Nismo, nažalost, mogle konzultirati taj primjerak jer se upravo prenosi u biblioteku Kule Jankovića u Islamu Grčkom.

16 Za pojam „kultura primateljica“ usp. Bruno Osıмo, Manuale del traduttore, Milano 2011., 274. O utjecaju povijesnog konteksta na prijevodne izbore usp. i Iva Grgić Maroević, Politike prevodenja. O hrvatskim prijevodima talijanske proze, Zagreb 2017., 57-76. 
Sol chi non lascia eredità d'affetti $\quad 40$

poca gioia ha dell'urna; e se pur mira

dopo l'esequie, errar vede il suo spirto

fra 'l compianto de' templi acherontei,

o ricovrarsi sotto le grandi ale

del perdono d'Iddio; ma la sua polve

lascia alle ortiche di deserta gleba

ove né donna innamorata preghi,

né passegger solingo oda il sospiro

che dal tumulo a noi manda Natura.

50

Ko $u$ amanet ne ostavlja ljubav

40

slabo mari za grob; al ako misli

što biva poslije pogreba; on vidi

svoj duh gdje luta sred hadskoga plača

il gdje se sklanja pod široka krila

božjega oproštenja; ali prah mu

pod koprivom u pustoj grudi leži

gdje niti moli zaljubljena žena

nit usamljeni putnik čuje uzdah

što ispod humka do nas šalje Narav.

Središnji dio Foscolova epa počinje sljedećim, 51. stihom, u kojem se spominje novi zakon:

Pur nuova legge impone oggi i sepolcri 51

Fuor de' guardi pietosi, e il nome a' morti

Contende. E senza tomba giace il tuo

Sacerdote, o Talia, che a te cantando

Nel suo povero tetto educò un lauro

Con lungo amore, e t’appendea corone; 56

Sad novi zakon izuzimlje groblja

od samilosnih pogleda, a ime

umrlim krati. Pa bez groba leži

i tvoj, Talijo, sveštenik što pojuć

pod bijednim krovom odnjegova lovor

s ljubavlju dugom, ovjenčav te vijencem. 56

Uz ovaj je fragment zanimljiv i opširan prevoditeljev komentar u kojem se navodi da Foscolo „vjerovatno ne misli na neki određeni zakonski propis (komentatori nagađaju da li se ti stihovi odnose na Napoleonov dekret od 5. IX 1806, ili onaj iz 1804, ili na neki 
raniji dekret Marije Terezije, i. t. d.), nego uopće na savremene uredbe i običaje koje je zavela Francuska revolucija, a koje su zabranjivale da se mrtvi pokapaju u crkvama i sl. veći jedino u naročitim javnim grobištima van gradskih naselja“ ${ }^{17} \mathrm{Za}$ antonomaziju „sveštenik Talije“ („muze komedije, pa i komične poezije uopće“) piše da je to „pjesnik Giuseppe Parini“, za kojeg navodi i precizne podatke jer je on, „izuzev talijaniste, manje poznat u hrvatskoj kulturi“. Parinijev Milano („la città lasciva / d'evirati cantori allettatrice“, 73-74) u prijevodu je „varoš bludna / što mazi škopce-pjevače“; u bilješci je, znanjem nesuđenog pjevača, opisan kao grad „poznat po staroj tradiciji kazališnog života, naročito opere. Još u Foscolovo vrijeme bili su u Milanu na velikoj cijeni neki pjevači-eunusi kao na pr. poznati Marchesi “. 18

Zaključni dio spjeva odnosi se na Kasandrin plač, koji se uvodi stihovima 258-262: „Tu i Kasandra, kad joj Feb iz grudi / stade proricat Trojin smrtni danak, / dođe i groblju pjesmu punu milja / razveza; vodi bratiće, pa i njih / nejake uči žalopojki nježnoj." U opsežnoj bilješci uz 258. stih, koju čitamo na 3. stranici pronađenog strojopisa, nalazimo važnu prevoditeljsku opasku:

Ona vodi na Ilov grob bratiće (...) i uči ih naricati pretskazujući im da će dopasti u sužanjstvo poslije propasti i porušenja njihova grada. Prevodioci ih mahom nazivlju Kasandrinim unucima, valjda stoga što talijanska riječ nipote označava i unuka i sinovca i nećaka i bratića; ali jasno je da se ovdje ne radi o unucima nego baš o bratićima, djeci Kasandrine pedesetero braće, jer Kasandra kao djevica-proročica, nije imala djece, pa ni unuka.

Odatle zaključujemo da je Desnica poznavao neke od ranijih prijevoda Foscolova epa jer originalne „nepote“ prevode kao „unuke“ Vežić (1870.), Svilović (1885.) i Sasso (1902.), Buzolić (1879.), Tomanović (1883.), Car (1887.) i Ilijić (1905.) prevode ih kao „unučad“, Lozovina (1911.) kao „unučićc“, dok ih je Trnski (1869.) preveo kao „netjačiće“, a Nazor (1939.) i Desnica kao „bratiće“. ${ }^{19}$ U prijevod Boška Desnice taj stih nije uključen, ali je on u 266. stihu Kasandrina upravnog govora unio vokativ „djeco“. ${ }^{20}$ Kasandrino naricanje počinje 263. stihom pa navodimo završni fragment, stihove 283-295:

(...) Gemeranno gli antri

Secreti, e tutta narrerà la tomba

Ilio raso due volte e due risorto

Splendidamente su le mute vie

Per far più bello l'ultimo trofeo

Ai fatali Pelidi. $I l$ sacro vate,

Placando quelle afflitte alme col canto,

I Prenci Argivi e ternerà per quante

Abbraccia terre il gran padre Oceano.

\footnotetext{
17 V. D[esnica], „Bilješke o ‘Grobovima’ Uga Foscola“, 386.

18 Isto.

19 J. Jernej, „Foscolo presso i Croati e i Serbi“, 27-31.

20 U. Foskolo, „Kasandrin plač. Ulomak iz 'Grobova'“, 267.
} 
E tu onore di pianti, Ettore, avrai

Ove fia santo e lagrimato il sangue

Per la patria versato, e finchè il Sole

Risplenderà su le sciagure umane.

(...) Ječati će špilje

tajne, svo groblje pričat će o Troji

sraženoj dvaput, dvaput uskrsnuloj

u sjaju svom na ulicama nijemim

da još uljepša zadnji trofej kobnoj

djeci Peleja. Taj svešteni pjesnik

blažeći pjesmom ojađene duše

argivske vode ${ }^{21}$ veličat će širom

zemalja što Ocean-otac paše.

A ti ćeš imat, Hektore, čast suza

gdje je god sveta i čašćena krvca

prosuta za dom, i dokle god Sunce

Nad nevoljama ljudskim bude sjalo!

Kao ilustraciju različite prevoditeljske poetike citiramo i prijevod Boška Desnice iz 1910. godine:

(...) Zaječaće špilje,

A grob će pričat' kako dvaput Troja

Pade i dvaput vaskrese, da samo

Zasija ljepša uresnim Pelidom

Pobjeda zadnja. Osveštani pjesnik,

Tužne će one duše pjesmom tješit',

I grčkim slavu provodit' herojim

Gde gde god Okean zemlju valom paše.

A ti ćeš plača počast imat svugđe,

Hektore, gđe se krvca prolivena

Za otadžbinu sveta, dok god sunce

Nad udesima ljudskim sjalo bude.

Dok originalni stihovi 283-291 sadrže šest enjambementa, u prijevodu Vladana Desnice čak ih je osam! Foscolove stihove „(...) e tutta narrerà la tomba / Ilio raso due volte e due risorto“ Desnica je preveo kao „svo groblje pričat će o Troji / sraženoj dvaput, dvaput uskr-

$\overline{21}$ Na ovom se mjestu očigledno radi o tiskarskoj pogrešci, što je razvidno iz 4. stranice bilješki u strojopisu koje nedostaju u Hrvatskom kolu. Ovdje je u komentaru uz 290. stih Desnica zapisao: „'argivske vođe’ - grčki vođe. Homer će, kao Grk, u prvom redu slaviti Grke, kao sunarodnjake i pobjednike, ali će i Trojanci, među njima naročito Hektor, biti slavljeni i čašćeni svuda gdje se slavi i časti krv prolivena za dom. “ Još jednu tiskarsku pogrešku primijetile smo u 32. stihu prijevoda, gdje je otisnuto neispravno „živeš“, umjesto evidentnog 2. lica jednine „živiš̌“. U Desničinoj mapi „Foscolo 1778-1827“ nalaze se stranice iz Hrvatskog kola na kojima je prevodilac svojom rukom unio još neka bolja rješenja i ispravke otisnutog teksta pa je tako i riječ „Vode“ ispravljena u „Vođe“. 
snuloj“ (284-285), prenijevši metonimiju „tutta tomba“ efektnom zbirnom imenicom „svo groblje“, dok je sintagma „Ilio raso“ očuvana kao „Troja sražena“, u značenju „biti sravnjena sa zemljom“, od glagola „sraziti, sravniti“. „Fatali Pelidi“ prevedeni su kao „kobna djeca Peleja“, a zanimljivo je rješenje za „il sacro vate“ (doslovce, „,sveti prorok“, 22 ovdje primijenjeno na Homera). U Desnice se javlja „taj svešteni pjesnik“, gdje je pokazna zamjenica „taj“ ekvivalent za talijanski određeni član „il“, koji proroka, pjesnika označuje jedinstvenim. Talijanski gerund „placando“, koji označuje paralelnu radnju, u ovom slučaju s futurom „eternerà“, Desnica je spretno preveo također glagolskim prilogom sadašnjim „blažeći“ u smislu „ublažavajući boli, tješeći“, što stoji u korelaciji s „veličat će“ (doslovan prijevod bio bi: „ovjekovječivat ć“", no to rješenje bilo bi neprihvatljivo zbog prevelikog broja slogova). „Per quante abbraccia terre il gran padre Oceano“ sažeto je u prijevodu potpunim ekvivalentom „širom zemalja što Ocean-otac paše“ u smislu „opasavati, doticati“, a „prenci Argivi“ u prijevodu su „argivske vođe“ u skladu s Maretićevim prijevodom Ilijade, što je i potvrđeno na 4. stranici komentara sačuvanog u strojopisu. ${ }^{23}$ I posljednja su tri enjambementa očuvana u prijevodu: „onore di pianti“ jest „čast suza“, „santo e lacrimato il sangue / per la Patria versato“ u Desničinu je prijevodu „sveta i čašćena krvca / prosuta za dom“, u skladu s izborom jednosložnih ili kraćih riječi koje čuvaju duljinu stiha.

Kada je riječ o semantici poetskog teksta, konstatiramo da su u prijevodu očuvane tematske (ključne, konceptualne) riječi: urna, tomba, esequie, polve, gleba, tumulo u prijevodu su grob, žara, pogreb, prah, gruda, humak, ne uvijek kao ekvivalenti, ponegdje i kao sinonimi. Zanimljivo je prijevodno rješenje u 40. stihu, u originalu „sol chi non lascia eredità di affetti“ (= samo onaj tko u nasljeđe ne ostavlja osjećaje), što Desnica prevodi ovako: „Ko u amanet ne ostavlja ljubav“ i formulira iskaz snažnije regionalizmom „amanet“, arabizmom koji smo usvojili kao turcizam, zbog čega je iskaz ne samo sročen u duhu kulture primateljice nego i osnažen markiranom riječju. No, u Foscolov klasicistički visoki stil Desnica uvodi i neke druge karakteristične lekseme u duhu kulture primateljice i nekih njezinih regionalnih izraza, za što navodimo nekoliko primjera: „igralo bude kolo“ za „danzeran“ (= plesat će, stih 7); „mili druže“ za „dolce amico“ (= mili, slatki prijatelju, 8); „za dom“ za „per la patria“ (= za domovinu, 294); „zaman“ za „invan“ (= zalud, 266); „míri“ za „le mura“ (= zidine, 267); „plačem udovičkijem“ za „vedovili lagrime“ (= udovičke suze, 273-274); „pređi“ za „padri“ (= oci, očevi, 275); „bradva“ za „la scure“ (= sjekira, 275); „čašćena krvca“ za „lagrimato sangue“ (= oplakana krv, 293).

$\mathrm{Na}$ temelju provedene usporedbe Foscolova originala s Desničinim prijevodom ${ }^{24}$ razvidne su temeljne karakteristike novonastalog metateksta, koje iskazuju visok stupanj poklapanja $s$ versifikacijskim, pjesničko-sintaktičkim i semantičkim osobinama njegova prototeksta. U metatekstu su i u obliku i u broju očuvani nerimovani jedanaesterci (lišeni za talijansku poeziju karakterističnih sinalefa) te, dobrim dijelom, u Foscola frekventna opkoračenja. Manja očuvanost originalne interpunkcije treba se pripisati različitosti sintaktičkih struktura dvaju jezika, a povremena promjena reda riječi kako metričkim zahtjevima tako i nastojanju da

\footnotetext{
22 Tako ga prevodi i Frano Čale. Usp. Ugo Foscolo, Ode. Soneti. Grobovi (prev. Frano Čale), Zagreb 1991., 93.

23 Frano Čale tu sintagmu prevodi kao „kneževi grčki“. Usp. Isto.

24 Analizu smo provele temeljeći se na radu: Bruno Osımo, „Per un approccio scientifico alla valutazione delle traduzioni“ (https://rivistatradurre.it/2013/05/per-un-approccio-scientifico-alla-valutazione-delle-traduzioni/).
} 
se ne našteti sintetičnosti iskaza. Pronađen je adekvat za Foscolov visok jezični registar, koji nimalo ne gubi na težini uvođenjem nekih pučkih leksičkih rješenja u duhu kulture primateljice; dapače, rekle bismo da je njime obogaćen. Nadalje, i prisutnošću svih izvornih konceptualnih riječi (onih kojima se izražavaju nosivi pojmovi teksta, ${ }^{25}$ premda ne uvijek uz Foscolove majuskule) očuvana je univerzalna poruka teksta. Zaključujemo stoga da je Desničin prijevod njegovo autorsko čitanje Foscolovih Grobova kojim je taj kratki ep, što svojim pozivanjem na grobove velikana koje osnažuje suvremenike te prizivanjem cikličnosti Prirode, koje sve ljude čini velikom obitelji, funkcionira na više razina (klasičnoj, predromantičkoj, rodoljubnoj), ponudio na razmatranje sebi suvremenoj kulturi, 50-im godinama dvadesetog stoljeća.

Ovo prevedeno pjesničko djelo pretpostavlja obrazovanog čitatelja, u skladu s izdavačkom politikom zagrebačkog časopisa u kojem je objavljeno, a koji nudi prijevode klasikâ, visokovrijednih originala koji se prenose u kulturu primateljicu, ne zadovoljavajući se dotadašnjim polovičnim rješenjima, već tražeći u njoj svoje što adekvatnije mjesto. Radi se, prema našem mišljenju, o jednom od najzahtjevnijih, ako ne i najzahtjevnijem prevoditeljskom zadatku što ga je Desnica sebi postavio i ostvario. Njegovi prijevodni postupci, dostojni već zrele talijansko-hrvatske pjesničko-prijevodne tradicije, ne remete, već rekreiraju cjelovitu intenciju ove iznimne epistole koja je nadahnula talijanski Preporod i ostavila dubok trag u dalmatinskih intelektualaca ne samo 19. nego i 20. stoljeća. Desničina verzija Foscolovih Grobova još je jedan od pokazatelja kako je on, bez zastajanja na lokalnome, jedan od nezaobilaznih pripadnika toga zavičajnog misaonog i intelektualnog kruga.

\section{$\cos$}

\section{Izvori i literatura}

\section{Izvori}

Vladan Desnica, „Bilješke o ‘Grobovima’ Uga Foscola“, strojopis, Osobna ostavština Vladana Desnice u Zagrebu.

V[ladan] D[esnicA], „Bilješke o ‘Grobovima’ Uga Foscola“, Hrvatsko kolo, 4/1951., br. 3-4, 386-387. Vladan Desnica, „Ugo Foscolo (1778-1827.) (bilješka o piscu)“, Hotimično iskustvo: diskurzivna proza Vladana Desnice. Knjiga prva (prir. Dušan Marinković), Zagreb 2005., 251-252.

„Ugo Foscolo: Grobovi'. Prev. Vladan Desnica“, Hrvatsko kolo, 4/1951., br. 3-4, 281-287.

\section{Literatura}

Guido CavalCanti, „Balateta“, Hrvatsko kolo, 3/1950., br. 4, 652-653.

Boško Desnica, Sabrana djela (prir. Milorad Savić), Zagreb 2008.

Vladan Desnica, Eseji, kritike, pogledi (prir. Stanko Korać), Zagreb 1975.

Vladan DesnicA, „Guido Cavalcanti: uz prijevod 'balatete'“, Hrvatsko kolo, 3/1950., br. 4, 768-777.

Ugo Foscolo, Ode. Soneti. Grobovi (prev. Frano Čale), Zagreb 1991.

25 Usp. Isti, Traduzione e qualità, 156. 
Ugo Foscolo, Poesie e carmi. Poesie. Dei Sepolcri. Poesie postume. Le Grazie (prir. Francesco Pagliai, Gianfranco Folena i Mario Scotti), Firenze 1985.

Ugo Foskolo, „Kasandrin plač. Ulomak iz 'Grobova', Srpski književni glasnik, 10/1910., knj. $24,267-268$.

Iva Grgić Maroević, Poetike prevodenja. O hrvatskim prijevodima talijanske poezije, Zagreb 2009. Iva Grgić Maroević, Politike prevodenja. O hrvatskim prijevodima talijanske proze, Zagreb 2017. Josip Jernej, „Foscolo presso i Croati e i Serbi“, Studia Romanica et Anglica Zagrabiensia, 2/1957., br. 4, 3-31.

Dušan Marinković, „Popis kućne biblioteke Vladana Desnice“, Hotimično iskustvo: diskurzivna proza Vladana Desnice. Knjiga druga (prir. Dušan Marinković), Zagreb 2006., 251-279.

Bruno Osimo, Manuale del traduttore, Milano 2011.

Bruno Osımo, „Per un approccio scientifico alla valutazione delle traduzioni“ (https://rivistatradurre.it/2013/05/per-un-approccio-scientifico-alla-valutazione-delle-traduzioni/).

Bruno Osımo, Storia della traduzione, Milano 2002.

Bruno Osımo, Traduzione e qualità, Milano 2004.

Sanja Rorć, „Desnica i 'pramaljeće' talijanskog pjesništva“, Stranci. Portreti s margine, granice i periferije, Zagreb 2006., 144-157.

Sanja Rorć, „Dom predaka u Islamu grčkom kao pjesnički motiv. Jedna nepoznata pjesma na talijanskom jeziku iz arhiva obitelji Desnica“, Hrvatsko-srpski / srpsko-hrvatski interkulturalizam danas (ur. Drago Roksandić), Zagreb 2017., 307-319.

Sanja RoIć, „Dva pisca na meti kritike: Desnica i Silone“, Istočno i zapadno od Trsta. Interkulturalni dijalozi, Zagreb 2013., 122-141.

\section{$\cos$ \\ VLADAN DESNICA AS THE TRANSLATOR AND COMMENTATOR OF Foscolo's OF THE SEPULCHRES}

The translation of Ugo Foscolo's short epic poem Dei Sepulchri (Of the Sepulchres), published in the literary magazine Hrvatsko kolo in 1951 holds an important place in the work of Vladan Desnica. Ugo Foscolo (1778-1827) was an Italian poet, novelist, literary critic and translator, born in Greece and raised in Dalmatia (Split), according to his own testimony. His 1807 epic poem Of the Sepulchres made an impact on the the art of the Italian national revival and literature of his time in general. The epic poem was translated numerous times between 1869 and 1990 and published in literary magazines in Zagreb, Dubrovnik, Novi Sad, Mostar and Split. Among those, Vladimir Nazor's translation remains in manuscript form, whereas Desnica's is the eleventh. The most recent translation was published by Franjo Čale in the literary magazine Forum in 1990 and a year later in the edition of Ugo Foscolo's work Ode. Soneti. Grobovi (Odes. Sonnets, Sepulchres). The paper provides a traductological analysis of Desnica's translation and places the work in the wider context of his work as a translator from the Italian.

Key words: Ugo Foscolo, the epic poem Of the Sepulchres, translation from Italian into Croatian, unrhymed hendecasyllable, the symbolism and metaphor of the grave 